Check for updates

The BMJ

rcoombes@bmi.com Follow Rebecca on Twitter @rebeccacoombes Cite this as: BMJ2020;371:m3898 http://dx.doi.org/10.1136/bmj.m3898 Published: 08 October 2020

\title{
Covid-19: This time it's personal for GPs
}

\section{Rebecca Coombes head of news and views}

In general practice, waiting rooms are quiet, there are fewer locums, and, for now at least, the Care Quality Commission's inspectors aren't calling. But $B M J$ articles have captured the seismic effect of covid-19 on the delivery of primary care: the tensions, challenges, and emerging lessons. As health services brace for the effects of escalating covid-19 cases, it's clear this time around that management of patients needs to be different.

Sophie Park and colleagues say that GPs have been overlooked in this pandemic. ${ }^{1}$ They have been excluded from the Scientific Advisory Group for Emergencies (SAGE), NHS Test and Trace, and research studies. Tellingly, there is only one registered study of primary care covid-19 treatments, despite a need for research on early disease.

Instead, the clinical skills of GPs must be engaged to improve outcomes for the next wave of covid-19 patients. ${ }^{2}$ GPs are in pole position to care for those who survive initial infection but are left with longlasting mental and physical effects. ${ }^{3}$ With $30 \%$ of covid-19 deaths occurring in the community, there is also a need for end-of-life support at home.

On top of this, GPs need to prepare for a massive expansion of flu prevention and future covid-19 vaccination, as well as managing the accumulated backlog of acute and chronic illness.

It's no surprise the situation is causing heightened emotions. David Oliver and Helen Salisbury, respectively a hospital doctor and a GP, spot the tensions between these two groups of doctors. 45 Accident and emergency doctors are frustrated at dealing with patients who in "normal" times would go to their GP. In return, GPs are "muttering about feeling like community juniors," as they pick up work from stretched hospital outpatient clinics such as organising blood tests, says Salisbury.

Both doctors urge an end to what Oliver calls "reflexive antagonism," emphasising that there is more that unites than divides them. As winter looms, "NHS doctors need to present a united front and seek to influence national policy as allies."

Looking to the longer term, Martin Roland and colleagues ask which changes to general practice should stay and which should be jettisoned after the pandemic. ${ }^{6}$ The service is at a "fork in the road," where changes such as near $100 \%$ virtual consultations could become the norm unless checked. Although having fewer face-to-face consultations is certain, how can we avoid general practice becoming an "impersonal call centre?"

Look at the evidence, say the authors. Numerous studies show that continuity of care improves adherence to prescribed medications and is even associated with reduced mortality. They advise avoiding combined patient lists to maximise continuity, using alternatives to face-to-face consultations when possible, and providing 15 minute consultations in the clinic for patients who would benefit. These changes could make the difference between a personal and an impersonal future for general practice.

Park S, Elliott J, Berlin A, Hamer-Hunt J, Haines A. Strengthening the UK primary care response to covid-19. BM/2020;370:m3691. doi: 10.1136/bmi.m3691 pmid: 32978177

2 Greenhalgh T, Knight M, A'Court C, Buxton M, Husain L. Management of post-acute covid-19 in primary care. BMJ2020;370:m3026. doi: 10.1136/bmj.m3026 pmid: 32784198

3 Nabavi N. Long covid: How to define it and how to manage it. BMJ 2020;370:m3489. doi: 10.1136/bmj.m3489 pmid: 32895219

4 Oliver D. David Oliver: Don't let covid-19 drive a wedge between acute and primary care. BMJ2020;371:m3848doi: 10.1136/bmj.m3848.

5 Salisbury H. Helen Salisbury: Climbing out of our silos. BMJ 2020;371:m3875. doi: 10.1136/bmj.m3875 pmid: 33023891

6 Gray DP, Freeman G, Johns C, Roland M. Covid 19: a fork in the road for general practice. BMJ2020;370:m3709. doi: 10.1136/bmi.m3709 pmid: 32988832

This article is made freely available for use in accordance with BMJ's website terms and conditions for the duration of the covid-19 pandemic or until otherwise determined by BMJ. You may use, download and print the article for any lawful, non-commercial purpose (including text and data mining) provided that all copyright notices and trade marks are retained. 